Syntax Literate: Jurnal Ilmiah Indonesia p-ISSN: 2541-0849

e-ISSN: 2548-1398

Vol. 7, Special Issue No. 1, Januari 2022

\title{
EVALUASI PENCAPAIAN KEY PERFORMANCE INDICATOR (KPI) UNTUK MERANCANG TRAINING NEED ANALYSIS (TNA) KOMPETENSI GURU
}

\author{
Sri Wahyuni Nur Hidayah, Dian Hidayati, Herlin, Krisna Erwintha Putra
}

Universitas Ahmad Dahlan, Yogyakarta Indonesia

Email: sri2008046034@webmail.uad.ac.id,dian.hidayati@mp.uad.ac.id, herlin2008046042@webmail.uad.ac.id,krisna2008046027@webmail.uad.ac.id

\begin{abstract}
Abstrak
Evaluasi kinerja merupakan program yang harus diagendakan secara rutin oleh unit organisasi. Parameter yang digunakan akan lebih terukur dengan Key Performance Indicator. Obyektifitas evaluasi penilaian dengan KPI dapat dijadikan parameter Training Need Analiysis dalam peningkatan kompetensi guru. Kompetensi guru perlu di upgrade secara periodik sehingga target kinerja dapat diselesaikan dengan maksimal. Kinerja guru yang maksimal akan menghasilkan iklim pendidikan yang bermutu, siswa yang berprestasi dan sekolah yang berualitas. Penelitian ini menggunakan metode evaluatif diskriptif yang mendikripsikan hasil penelitian pencapaian Key performance indicator (KPI) sebagai dasar menyusun Training need analysis (TNA) untuk meningkatkan kompetensi guru. Penelitian ini dilakukan untuk menjawab permasalahan tentang follow up penilaian kinerja guru di Yayasan Bumitama yang belum ada klaster tepat dalam penilaian maupun dalam pelatihan. Penelitian evaluatif ini dapat memberikan masukan agar pelatihan yang akan dilaksanakan oleh Yayasan lebih spesifik dan merujuk kepada kebutuhan pendidik. Selain itu pelatihan seharusnya disesuaikan dengan satuan pendidikan sehingga kompetensi guru di satuan pendidikan dapat meningkat. Dari hasil pembahasan diperoleh kesimpulan bahawa Guru di Yayasan memerlukan pelatihan sebagai berikut: 1). Pelatihan Pengembangan Model Pembelajaran yang kreatif, inovatif dan menyenangkan untuk menginspirasi siswa dalam meningkatkan nilai hasil pembelajaran. 2). Pelatihan pembuatan Media pembejaran untuk SMP. 3). Pelatiahan Administrasi pendidikan guru untuk jenjang sekolah SD, SMP dan SMK di Yayasan sehingga semua guru merasa ikut bertanggungjawab terhadap kelengkapan administrasi pendidikan yang harus disiapkan oleh semua guru. 4). Pelatihan Teknologi Media Pembelajaran yang akan mengantarkan pendidikan era revolusi 4.0, yang menjadi tuntutan pendidikan saat ini.
\end{abstract}

Kata kunci: Evaluasi; KPI ; TNA; Kompetensi ; Guru

\section{Abstract}

Evaluation Achievement of Key Performance Indicators (KPI) to Designe Training Need Analysis (TNA) of Teacher Competencies at Yayasan Bumitama. Performance evaluation is a program that must be regularly scheduled by organizational units. The parameters used will be more measurable with Key

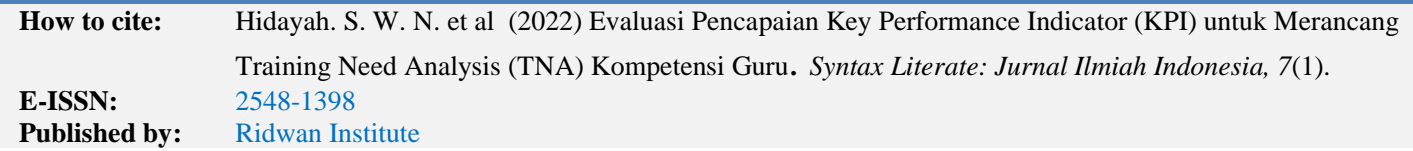


Performance Indicators. The objectivity of the evaluation assessment with KPI can be used to designe a Training Need Analysis in improving teacher competence. Teacher competencies need to be upgraded periodically so that performance targets can be completed to the maximum. Maximum teacher performance will result in a quality education climate, outstanding students and quality schools. This study uses a descriptive evaluative method that describes the results of research on the achievement of Key Performance Indicators (KPI) to disigne a Training Needs Analysis (TNA) to improve teacher competence. This study was conducted to answer problems regarding the follow-up of teacher performance assessments at the Bumitama Foundation where there is no appropriate cluster in the assessment or in training. This evaluative research can provide input so that the training to be carried out by Yayasan Bumitama is more specific and refers to the needs of educators. In addition, training should be adjusted to the education unit so that the competence of teachers in the education unit can increase. From the results of the discussion, it was concluded that teachers at the Bumitama Foundation needed the following training: 1). Creative, innovative and fun Learning Model Development Training to inspire students to increase the value of learning outcomes. 2). Training on making learning media for SMP Bumitama. 3). Educational administration training for elementary, junior high and vocational schools at Bumitama Foundation Schools so that all teachers feel they are responsible for the completeness of educational administration that must be prepared by all teachers. 4). Learning Media Technology Training that will deliver education in the 4.0 revolution era, which is the current demand for education.

Keywords: Evaluation; KPI; TNA; Competencies; Teacher

\section{Pendahuluan}

Kinerja guru sebagai pelaksana pendidikan nasional sangat diharapkan maksimal dalam mencapai tujuan umum pendidikan, yaitu mencerdaskan kehidupan bangsa. Dalam melaksanakan tupoksinya guru harus memiliki jiwa kepemimpinan dalam kegiatan Belajar mengajar. Kepemimpinan guru dalam pembelajaran sangat menentukan output pembelajaran yang sudah ditetapkan sebelumnya, baik kompetensi pengetahuan siswa maupun karakter siswa yang terbentuk melalui proses pembelajaran. Guru yang baik adalah seorang guru yang secara individu peduli terhadap perkembangan siswa, mampu mendedikasikan waktu dan energi dalam mengelola kelas, serta mampu menguasai materi pelajaran yang harus disampaikan kepada siswa-siswi di kelas yang diampunya. (Fatimaningrum, 2011). Guru yang baik akan menghasilkan pendidikan yang baik, karena pendidikan akan mampu membentuk perilaku manusia yang baik dan sesuai dengan tuntutan jaman serta dapat menjadi wahana dalam mempersiapkan generasi milenial. Hal senada dituliskan oleh (Rahman, Sakti, Widya, \& Yugafiati, 2019).

Untuk mengetahui sejauhmana tujuan pembelajaran tercapai perlu dilaksanakan evaluasi pencapaian kinerja guru. Pencapaian kinerja dapat diketahui dari penilaian kinerja tahunan yang dikenal dengan Performance Appraisal. Pencapaian kinerja ini dapat digunakan alat ukur yang tercakup dalam indikator kinerja atau Key Performance 
Indicator. Key Performance indicator sebagai alat evaluasi keberhasilan program kerja yang sudah di tetapkan sebelumnya dan dapat dijadikan parameter kesuksesan dalam pelaksanaan program kerja (Flipse, 2019).

Indikator kinerja guru seharusnya dapat dicapai dengan maksimal sebagai bukti kompetensi yang dimiliki oleh guru dalam melaksanakan tupoksinya. Dengan kata lain bahwa guru yang kompeten adalah guru yang dapat mencapai hasil kinerja dengan pencapaian maksimal. Batas nilai maksimal antar instansi pendidikan berbeda antara yang satu dengan yang lainnya. Dalam hal ini, sebuah instansi pendidikan sudah menentukan indikator yang harus dicapai dan bobot penilaian yang sudah ditetapkan sebelumnya.

Permasalahan yang menjadi dasar penilitian ini adalah: 1). Belum adanya Training Need Analysis yang lebih spesifik dari hasil pencapaian KPI Guru Yayasan Bumitama, sesuai dengan kebutuhan guru dalam meningkatkan kompetensinya. 2). Pencapaian Key Performance Indicator guru masih direkap secara acak tanpa memisahkan jenjang pendidikan yang ada, sehingga dalam pemberian fasilitas peningkatan kompetensi guru belum sesuai dengan jenjang pendidikan yang diampu oleh guru. Yang sudah dilaksanakan adalah memberikan atau mengikuti pelatihan baik seminar maupun webinar yang masih bersifat umum tanpa melakukan analisis terhadap kebutuhan peningkatan kompetensi atas dasar hasil pencapaian KPI yang sudah ditetapkan sehingga belum dapat memberikan fasilitas peningkatan kompetensi atas dasar kebutuhan guru dari empat jenjang pendidikan yang ada, misalnya beberapa guru masih memerlukan pendampingan dalam mengenal metode pembelajaran yang efektif sesuai dengan jenjang pendidikan yang diampu di sekolah Yayasan dan beberapa lainnya memerlukan pendampingan dalam pengembangan inovasi pembelajaran.

Obyek penelitian dalam artikel ini adalah guru di Sekolah Yayasan yang diambil dari unit sekolah TK/PAUD, SD, SMP dan SMK yang berada di Kabupaten Kotawaringin Timur, Kalimantan Tengah sebagai sample. Dari penelitian ini diharapkan ada tindak lanjut terhadap hasil penilaian kinerja dengan evaluasi pencapaian Key Performance indicator, sehingga akan diperoleh peringkat dari hasil penilaian dan selanjutnya dapat diberikan apresiasi bagi guru dengan pencapaian maksimal serta akan diperoleh analisa kebutuhan pembinaan atau Training Need Analysis guna meningkatkan kompetensi guru.

\section{Metode Penelitian}

Penelitian ini menggunakan metode evaluative diskriptif, yang akan mendiskripsikan hasil penelitian dengan data kuantitatif yang diperoleh dengan penarikan data hasil pencapaian Key Performance Indicator Guru di sebuah Yayasan Bumitama, dalam Performance Appraisal tahun 2020. Dari data yang diproleh akan diolah dengan tabel rekapitulasi pencapaian KPI guru dan kemudian ditetapkan peringkat, diklasifikasikan sesuai dengan nilai pencapaian KPI tahun 2020 dengan hasil akhir menyimpulkan hasil penelitian untuk dibuatkan Training Need Analysis kompetensi guru. 


\section{Hasil dan Pembahasan}

\section{Pokok Bahasan}

Evaluasi Pencapaian Key Performance Indicator (KPI) sebagai dasar Penyusunan Training Need Analysis (TNA) Kompetensi Guru di Yayasan Bumitama akan dibahas secara runtut sebagai berikut:

a. Evaluasi

Evaluasi merupakan saduran dari bahasa Inggris "evaluation" yang diartikan sebagai penaksiran atau penilaian. Nurkancana (1983) menyatakan bahwa evaluasi adalah kegiatan yang dilakukan berkenaan dengan proses untuk menentukan nilai dari suatu hal. Sementara Raka Joni (1975) menjelaskan bahwa evaluasi adalah proses untuk mempertimbangkan sesuatu barang, hal atau gejala dengan mempertimbangkan beragam faktor yang kemudian disebut Value Judgment. (Wikipedia bahasa Indonesia, ensiklopedia bebas. 23 Maret 2021. Web 23 Maret 2021. https://id.wikipedia.org/wiki/Evaluasi.

Evaluasi diperlukan untuk memastikan bahwa program yang sudah direncanakan terlaksana, tercapai sesuai standard dan hasilnya juga sesuai dengan standar yang sudah ditetapkan (Zubaidi, 2020).

Dari pengertian diatas, evaluasi digambarkan sebgai proses dalam penilaian, sehingga aspek nilai dari sebuah pengukuran merupakan hal yang ditekankan dalam evaluasi. Evaluasi sering juga disebut dengan istilah Assessment. (Arifandi, 2020).

b. Key Performance Indicator (KPI)

Key Performance indicator (KPI) digunakan oleh unit organisasi yang membutuhkan tool atau alat dalam menilai kinerja staf dan karyawannya. Berikut adalah pengertian KPI menurut para ahli:

1. Menurut (Gabcanova, 2012) , Key Performance Indicator (KPI) adalah

2. ukuran yang bersifat kuantitatif dan bertahap bagi perusahaan serta memiliki berbagai perspektif dan berbasiskan data konkret, dan menjadi titik awal penentuan tujuan dan penyusunan strategi organisasi.

2. Menurut Banerjee dan Buoti (2012) dalam (Nurwahidah, Sawal, Mulyadi, Afifudin, \& Sari, 2021), KPI merupakan ukuran berskala dan kuantitatif yang digunakan untuk mengevaluasi kinerja organisasi dalam tujuan mencapai target organisasi.

3. Menurut (Parmenter, 2015) mendefinisikan Key Performance Indicator (KPI) yaitu sekumpulan indikator yang diciptakan terfokus kepada aspek kinerja organisasi yang paling kritikal untuk kesuksesan organisasi pada kondisi sekarang dan di masa dating.

4. Menurut (Warren, 2011), KPI adalah parameter yang mengevaluasi bagaimana sebuah perusahaan menjalankan visi strategisnya. Istilah visi strategis mengacu pada bagaimana strategi interaktif diintegrasikan ke dalam strategi perusahaan secara keseluruhan.

Dari beberapa pendapat diatas dapat disimpilkan bahwa Key Performance 
Indicator (KPI) merupakan alat ukur yang menjadi parameter penilaian kinerja untuk mengukur dan megevaluasi kesuksesan program yang sudah ditetapkan dalam mencapai visi dan misi. Penetapan indikator kinerja antar unit organisasi berbeda satu dengan yang lainnya.

c. Training Need Analysis (TNA)

Training Need Analysis adalah analisa kebutuhan pelatihan bagi staf dan karyawan yang bekerja di unit organisasi. Training Need Analysis disusun setelah evaluasi dan penarikan data sehingga memiliki dasar yang kuat dalam perencanaan program pelatihan, analisa ini merupakan parameter dalam pelaksanaan pelatihan SDM. Hal senada juga dikuatkan oleh (Amin \& Nurhadi, 2020) dimana dalam merancang pelatihan diperlukan adanya analisis yang menggambarkan keadaan real dilapangan dengan standar yang seharusnya ada dilapangan tupoksi guru.

Training Need analysis yang berpedoman pada pencapaian Key Performance Indicator dinilai lebih obyektif dan tidak memihak terutama oleh pihak-pihak yang menduduki jabatan fungsional maupun structural (Ningtyas \& Sutrisno, 2020).

d. Kompetensi Guru

Guru adalah tokoh utama dalam pendidikan karena langsung bersinggungan dengan peserta didik. Keberhasilan dalam pendidikan sangat dipengaruhi oleh kemampuan guru dalam melaksanakan kegiatan belajar mengajar dan dalam penguasaan kelas. Kemampuan guru ini disebut sebagai kompetensi guru. Kompetensi yang harus dimiliki oleh seorang guru, meliputi beberapa hal, seperti yang terkandung dalam Undang-undang Republik Indonesia No.14 Tahun 2005 tentang Guru dan Dosen, yaitu kompetensi pedagogik, kepribadian, sosial, dan kemampuan professional.

Guru banyak mengalami tantangan dalam profesinya, selain memiliki kemampuan mengajar guru juga harus memiliki kemampuan berkomunikasi yang baik dengan peserta didik, wali murid juga dengan teman seprofesi dan dengan tenaga kependidikan (Fatimaningrum, 2011). Selain itu seorang guru dalam melaksanakan kegiatan pembelajaran juga berfungsi sebagai motivator dan fasilitator bagi siswa dalam tumbuh kembang minat dan bakat serta menjaga semua fasilitas pembelajaran yang tersedia sehungga pembelajaran dapat terlaksana secara kondusif (Qurbani, 2017).

Selain kondusifitas kegiatan pembelajaran, seorang guru perlu mencermati perkembangan peningkatan nilai peserta didiknya, guru dituntut kreatif, inovatif dan menyenangkan sehingga mampu mendongkrak effort siswa dalam perolehan nilai hasil belajarnya (Siregar, Wardani, \& Hatika, 2017). Hal ini juga dikuatkan oleh (Pebrianto \& Noor, 2015), yang menulis artikel tentang Pengaruh Kreativitas Guru Mengajar Dan Minat Belajar Siswa Terhadap Hasil Prestasi Siswa Kelas Xi Jurusan Ips Di SMAN Karubaga Kabupaten Tolikara.

\section{Hasil Penelitian}

Dari hasil penelitian tentang Pencapaian Key performance Indikator (KPI) Guru Yayasan Bumitama tahun 2020 diperoleh data sebagai berikut :

a. Tabel pencapaian Key Performance Indicator tertera dalam gambar Performance contract Guru Yayasan Bumitama sebagai berikut : 


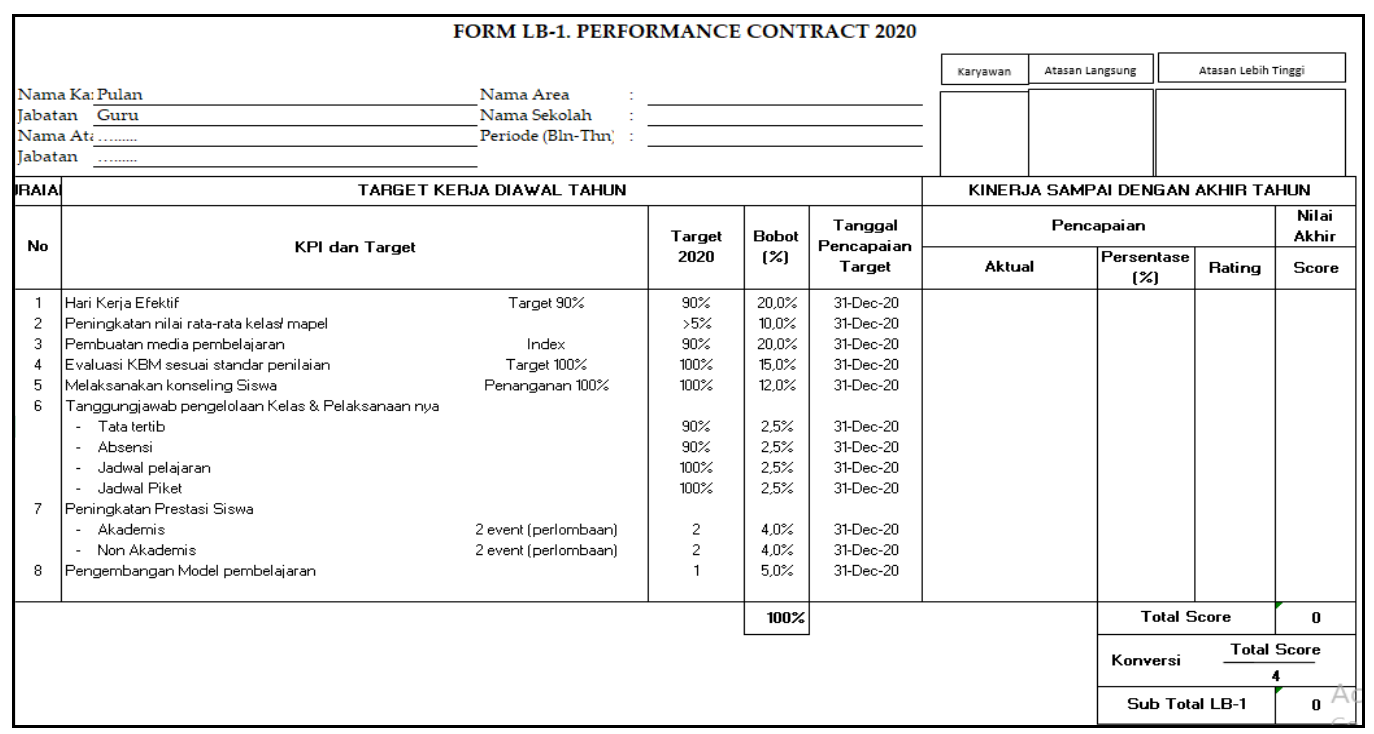

Gambar 1.

Tabel Performance Contract

b. Indikator Kinerja Guru dari gambar 1, yang sudah ditetapkan terdiri dari:

1. Hari Kerja Efektif

2. Peningkatan nilai rata-rata kelas/ maple

3. Pembuatan media pembelajaran

4. Evaluasi KBM sesuai standar penilaian

5. Melaksanakan konseling Siswa

6. Tanggungjawab pengelolaan Kelas \& Pelaksanaan nya :

a. Tata tertib

b. Jadwal pelajaran

c. Jadwal Piket

7. Peningkatan Prestasi Siswa

1. Akademis

2. Non Akademis

8. Pengembangan Model pembelajaran

Keterangan masing-masing poin dari Key Performance Indicator

1. Hari Kerja Efektif , ditarik dari data input BPS kehadiran karyawan

2. Peningkatan nilai rata-rata kelas/ maple, dirarik dari dashboard pengolahan nilai guru permapel/perkelas

3. Pembuatan media pembelajaran, ada 5 item yang wajib dijadikan bukti data pendukung, yaitu : Analisa perhitungan Hari Efektif, Program tahunan, program semester, Rencana Pembelajaran, dan perhitungan Kriteria Ketuntasan Minimal (KKM).

4. Evaluasi KBM sesuai standar penilaian, data pendukung guru dalam Performance Appraisail terdiri dari: Soal evaluasi pembelajaran, rekap 
ketuntasan peserta didik, dengan di lampirkan langkah yang diambil jika peserta didik tidak tuntas.

5. Melaksanakan konseling Siswa, dibuktikan dengan buku pembinaan yang ditandatangani oleh guru konselor dan orang tua muted.

6. Tanggungjawab pengelolaan Kelas \& Pelaksanaan nya :

a. Tata tertib, bukti pendudkungnya adalah tata tertib sekolah yang diturunkan dalam tata tertib kelas dan kontrak belajar.

b. Absensi, bukti pendukung adalah absensi manual dari hari efektif sekolah

c. Jadwal pelajaran, bukti pendukung adalah Jadwal pelajaran dan jadwal extra kurikuler.

d. Jadwal Piket, bukti pendukung berupa jadwal piket kelas, dan jadwal PIC untuk petugas UKS.

7. Peningkatan Prestasi Siswa

a. Akademis, data ditarik dari perolehan prestasi siswa yang diampu dalam kejuaraan olimpiade dengan target berjenjang, 3 besar tingkat kecamatan, 3 besar tingkat Kabupaten dan seterusnya.

b. Non Akademis, data ditarik dari perolehan prestasi siswa yang diampu dalam kejuaraan olimpiade pengembangan diri baik yang diadakan oleh Dinas Pendidikan maupun dinas pemerintahan yang lain.

8. Pengembangan Model pembelajaran, data pendukung harus melampirkan inovasi pembelajaran baik soft file maupun hard file, dengan target 4 (empat) item pengembangan model pembelajaran.

\section{Pengolahan Data}

Dalam penilitian ini penulis mendapatkan data hasil observasi dari Pencapaian Key Performance Indicator Guru di Sekolah Yayasan daerah Kotawaringin Timur dari jenjang pendidikan TK/PAUD, SD. SMP dan SMK. 
Tabel 1.

Rekap Performance Appraisal tahun 2020

Pencapaian Key Performance Indicator Guru

Sekolah Yayasan

\begin{tabular}{|c|c|c|c|c|c|c|c|c|c|c|c|c|c|c|c|c|}
\hline \multirow{4}{*}{ No } & \multirow{4}{*}{ NIK } & \multirow{4}{*}{ NAMA KARYAWAN } & \multirow{4}{*}{$\begin{array}{c}\text { unit } \\
\text { sekolah }\end{array}$} & \multicolumn{13}{|c|}{ Performance Contract (PC) / LB-1 } \\
\hline & & & & \multicolumn{5}{|c|}{ Key Performan } & \multicolumn{7}{|c|}{ Key Performance Indicator } & \multirow{2}{*}{$\begin{array}{l}\text { NIllai } \\
\text { LB-1 }\end{array}$} \\
\hline & & & & \multirow{2}{*}{. } & \multirow[t]{2}{*}{2} & \multirow[t]{2}{*}{3} & \multirow{2}{*}{4} & 5 & 61 & & 63 & & 71 & 77 & 8 & \\
\hline & & & & & & & & $10 \%$ & $\frac{0.1}{2,5 \%}$ & $\frac{6.2}{2.5 \%}$ & $\frac{6.3}{2.5 \%}$ & $\frac{6.4}{2,5 \%}$ & $\frac{7.1}{5 \%}$ & $\frac{7.2}{5 \%}$ & $10 \%$ & \\
\hline 1 & & 2 & 3 & 4 & 5 & 6 & 7 & 8 & 9 & 10 & 11 & 12 & 13 & 14 & 15 & 16 \\
\hline 1 & 00065 & Person 1 & TK & 80 & 40 & 20 & 60 & 12 & 2,5 & 10 & 10 & 7,5 & 0 & 2,5 & 0 & 61,13 \\
\hline 2 & 00022 & Person 2 & TK & 80 & 40 & 20 & 60 & 24 & 5 & 10 & 10 & 7,5 & 0 & 2,5 & 0 & 64,75 \\
\hline 3 & 00063 & Person 3 & TK & 80 & 40 & 20 & 60 & 24 & 10 & 10 & 10 & 7,5 & 0 & 2,5 & 0 & 66,00 \\
\hline 4 & 000312 & Person 4 & TK & 80 & 40 & 80 & 30 & 24 & 5 & 7,5 & 5 & 5 & 0 & 2,5 & 0 & 69,75 \\
\hline 5 & 00075 & Person 5 & SD & 80 & 30 & 20 & 60 & 48 & 2,5 & 10 & 10 & 10 & 0 & 2,5 & 0 & 68,25 \\
\hline 6 & 00007 & Person 6 & SD & 80 & 30 & 20 & 60 & 48 & 2,5 & 10 & 10 & 10 & 0 & 0 & 0 & 67,63 \\
\hline 7 & 00139 & Person 7 & SD & 80 & 30 & 20 & 60 & 48 & 2,5 & 10 & 10 & 10 & 0 & 0 & 0 & 67,63 \\
\hline 8 & 00140 & Person 8 & SD & 80 & 10 & 80 & 60 & 12 & 2,5 & 10 & 10 & 10 & 0 & 0 & 0 & 68,63 \\
\hline 9 & 00049 & Person 9 & SD & 80 & 20 & 20 & 60 & 48 & 10 & 10 & 10 & 10 & 0 & 2,5 & 2,5 & 68,25 \\
\hline 10 & 00005 & Person 10 & SD & 80 & 40 & 20 & 45 & 36 & 2,5 & 10 & 10 & 10 & 0 & 2,5 & 0 & 64,00 \\
\hline 11 & 00270 & Person 11 & SD & 80 & 20 & 20 & 45 & 36 & 2,5 & 10 & 10 & 7,5 & 0 & 2,5 & 0 & 58,38 \\
\hline 12 & 00175 & Person 12 & SD & 80 & 40 & 20 & 45 & 36 & 2,5 & 10 & 10 & 10 & 0 & 0 & 0 & 63,38 \\
\hline 13 & 00176 & Person 13 & SD & 60 & 30 & 20 & 45 & 48 & 2,5 & 10 & 10 & 10 & 0 & 2,5 & 0 & 59,50 \\
\hline 14 & 00217 & Person 14 & SD & 60 & 10 & 80 & 45 & 36 & 2,5 & 10 & 10 & 10 & 2,5 & 2,5 & 5 & 68,38 \\
\hline 15 & 00127 & Person 15 & SD & 80 & 40 & 0 & 45 & 36 & 2,5 & 10 & 10 & 10 & 0 & 2,5 & 2,5 & 59,63 \\
\hline 16 & 00269 & Person 16 & SD & 60 & 10 & 80 & 45 & 36 & 2,5 & 10 & 10 & 10 & 2,5 & 2,5 & 5 & 68,38 \\
\hline 17 & 00121 & Person 17 & SD & 80 & 40 & 20 & 45 & 48 & 2,5 & 10 & 10 & 10 & 2.5 & 2,5 & 2,5 & 67,63 \\
\hline 18 & 00006 & Person 18 & SD & 80 & 20 & 20 & 45 & 36 & 2,5 & 10 & 10 & 10 & 0 & 2,5 & 0 & 59,00 \\
\hline 19 & 00048 & Person 19 & SD & 80 & 20 & 20 & 60 & 36 & 2,5 & 10 & 10 & 10 & 0 & 0 & 0 & 62,13 \\
\hline 20 & 00453 & Person 20 & SMP & 60 & 20 & 20 & 45 & 36 & 10 & 10 & 10 & 10 & 2,5 & 0 & 2,5 & 56,50 \\
\hline 21 & 00231 & Person 21 & SMP & 80 & 30 & 20 & 45 & 12 & 10 & 10 & 10 & 10 & 0 & 0 & 0 & 56,75 \\
\hline 22 & 00473 & Person 22 & SMP & 80 & 30 & 20 & 15 & 12 & 7,5 & 10 & 10 & 10 & 2,5 & 2,5 & 0 & 49,88 \\
\hline 23 & 00182 & Person 23 & SMP & 60 & 30 & 20 & 45 & 48 & 10 & 10 & 10 & 2,5 & 2,5 & 2,5 & 2,5 & 60,75 \\
\hline 24 & 00086 & Person 24 & SMP & 60 & 10 & 20 & 45 & 24 & 10 & 10 & 10 & 10 & 0 & 2,5 & 2,5 & 51,00 \\
\hline 25 & 00464 & Person 25 & SMP & 60 & 30 & 20 & 30 & 24 & 10 & 10 & 10 & 10 & 2,5 & 5 & 5 & 54,13 \\
\hline 26 & 00089 & Person 26 & SMP & 40 & 30 & 20 & 45 & 36 & 10 & 10 & 10 & 10 & 0 & 5 & 2,5 & 54,63 \\
\hline 27 & 00303 & Person 27 & SMP & 60 & 30 & 60 & 30 & 24 & 10 & 10 & 10 & 10 & 2,5 & 5 & 5 & 64,13 \\
\hline 28 & 00010 & Person 28 & SMP & 40 & 20 & 20 & 45 & 36 & 10 & 10 & 10 & 10 & 0 & 2,5 & 2,5 & 51,50 \\
\hline 29 & 00076 & Person 29 & SMP & 60 & 20 & 20 & 45 & 36 & 10 & 10 & 10 & 10 & 0 & 2,5 & 2,5 & 56,50 \\
\hline 30 & 00142 & Person 30 & SMP & 80 & 30 & 80 & 15 & 0 & 10 & 10 & 10 & 10 & 0 & 2,5 & 2,5 & 62,50 \\
\hline 31 & 00108 & Person 31 & SMK & 80 & 20 & 80 & 45 & 24 & 10 & 10 & 7,5 & 7,5 & 2,5 & 5 & 2,5 & 73,50 \\
\hline 32 & 00177 & Person 32 & SMK & 80 & 20 & 60 & 45 & 36 & 10 & 10 & 7,5 & 7,5 & 0 & 2,5 & 2,5 & 70,25 \\
\hline 33 & 00096 & Person 33 & SMK & 60 & 20 & 80 & 45 & 36 & 10 & 10 & 7,5 & 7,5 & 2,5 & 2,5 & 2,5 & 70,88 \\
\hline 34 & 00162 & Person 34 & SMK & 80 & 30 & 40 & 30 & 36 & 10 & 10 & 7,5 & 7,5 & 2,5 & 2,5 & 2,5 & 64,63 \\
\hline 35 & 00034 & Person 35 & SMK & 80 & 20 & 20 & 30 & 12 & 10 & 10 & 7,5 & 7,5 & 0 & 2,5 & 2,5 & 50,50 \\
\hline 36 & 00101 & Person 36 & SMK & 80 & 30 & 80 & 45 & 36 & 10 & 10 & 7,5 & 7,5 & 5 & 5 & 5 & 80,25 \\
\hline 37 & 00129 & Person 37 & SMK & 80 & 30 & 20 & 30 & 24 & 5 & 10 & 7,5 & 7,5 & 2,5 & 2,5 & 2,5 & 55,38 \\
\hline 38 & 00080 & Person 38 & SMK & 80 & 30 & 40 & 15 & 36 & 10 & 10 & 7,5 & 7,5 & 0 & 0 & 2,5 & 59,63 \\
\hline 39 & 00130 & Person 39 & SMK & 80 & 20 & 40 & 30 & 36 & 10 & 10 & 7,5 & 7,5 & 5 & 5 & 2,5 & 63,38 \\
\hline 40 & 00152 & Person 40 & SMK & 80 & 40 & 20 & 30 & 48 & 26 & 10 & 6,5 & 5 & 5 & 5 & 2,5 & 69,50 \\
\hline 41 & 00452 & Person 41 & SD & 80 & 20 & 60 & 30 & 48 & 10 & 10 & 10 & 7,5 & 2,5 & 2,5 & 2,5 & 70,75 \\
\hline 42 & 00344 & Person 42 & SD & 80 & 30 & 80 & 30 & 36 & 10 & 10 & 10 & 7,5 & 0 & 2,5 & 2,5 & 74,63 \\
\hline 43 & 00357 & Person 43 & SD & 80 & 20 & 60 & 15 & 48 & 10 & 10 & 10 & 7,5 & 0 & 2,5 & 2,5 & 66,38 \\
\hline 44 & 00199 & Person 44 & SD & 60 & 30 & 60 & 60 & 36 & 10 & 10 & 10 & 7,5 & 2,5 & 2,5 & 2,5 & 72,75 \\
\hline 45 & 00431 & Person 45 & SD & 60 & 30 & 40 & 45 & 36 & 10 & 10 & 10 & 7,5 & 0 & 2,5 & 2,5 & 63,38 \\
\hline 46 & 00388 & Person 46 & SD & 60 & 20 & 40 & 45 & 48 & 10 & 10 & 10 & 7,5 & 0 & 2,5 & 2,5 & 63,88 \\
\hline 47 & 00274 & Person 47 & SD & 60 & 20 & 60 & 15 & 36 & 10 & 10 & 10 & 7,5 & 0 & 0 & 0 & 57,13 \\
\hline 48 & 00084 & Person 48 & TK & 80 & 20 & 60 & 30 & 24 & 10 & 10 & 10 & 7,5 & 2,5 & 0 & 2,5 & 64,13 \\
\hline 49 & 00293 & Person 49 & SD & 60 & 20 & 60 & 15 & 48 & 10 & 10 & 10 & 10 & 0 & 0 & 0 & 60,75 \\
\hline 50 & 00385 & Person 50 & SD & 60 & 40 & 80 & 30 & 0 & 10 & 10 & 10 & 10 & 2,5 & 2,5 & 2,5 & 64,38 \\
\hline 51 & 00273 & Person 51 & SD & 80 & 30 & 40 & 30 & 12 & 10 & 10 & 10 & 5 & 0 & 0 & 5 & 58,00 \\
\hline 52 & 00383 & Person 52 & TK & 80 & 30 & 60 & 30 & 36 & 10 & 10 & 10 & 5 & 0 & 0 & 0 & 67,75 \\
\hline
\end{tabular}

Dari data tabel 1, penulis akan mengklasifikan data acak atas dasar jenjang pendidikan, kemudian melakukan evaluasi terhadap hasil pencapaian Key Performance Indikator di Sekolah Yayasan dari rata-rata perjenjang pendidikan, untuk mendapatkan 
Evaluasi Pencapaian Key Performance Indicator (KPI) untuk Merancang Training Need Analysis (TNA) Kompetensi Guru

analisa pelatihan yang dibutuhkan atau Training Need Analyis berdasarkan jenjang Pendidikan.

Tabel 2.

Rekap Performance Appraisal tahun 2020

Pencapaian Key Performance Indicator Guru TK

\begin{tabular}{|c|c|c|c|c|c|c|c|c|c|c|c|c|c|c|c|c|}
\hline \multirow{4}{*}{ No } & \multirow{4}{*}{ NIK } & \multirow{4}{*}{ NAMA KARYAWAN } & \multirow{4}{*}{$\begin{array}{c}\text { unit } \\
\text { sekolah }\end{array}$} & \multicolumn{13}{|c|}{ Performance Contract (PC) / LB-1 } \\
\hline & & & & \multicolumn{12}{|c|}{ Key Performance Indicator } & \multirow{3}{*}{$\begin{array}{l}\text { NIlai } \\
\text { LB-1 }\end{array}$} \\
\hline & & & & \multirow{2}{*}{1} & \multirow{2}{*}{2} & \multirow{2}{*}{3} & \multirow{2}{*}{4} & \multirow{2}{*}{5} & \multicolumn{4}{|c|}{6} & \multicolumn{2}{|c|}{7} & \multirow{2}{*}{8} & \\
\hline & & & & & & & & & 6.1 & 6.2 & 6.3 & 6.4 & 7.1 & 7.2 & & \\
\hline & & & & $15 \%$ & $10 \%$ & $20 \%$ & $15 \%$ & $10 \%$ & $2,5 \%$ & $2,5 \%$ & $2,5 \%$ & $2,5 \%$ & $5 \%$ & $5 \%$ & $10 \%$ & $\begin{array}{l}\text { Total } \\
\text { Score }\end{array}$ \\
\hline 1 & & 2 & 3 & 4 & 5 & 6 & 7 & 8 & 9 & 10 & 11 & 12 & 13 & 14 & 15 & 16 \\
\hline 1 & 00065 & Person 1 & TK & 80 & 40 & 20 & 60 & 12 & 2,5 & 10 & 10 & 7,5 & 0 & 2,5 & 0 & 61,13 \\
\hline 2 & 00022 & Person 2 & TK & 80 & 40 & 20 & 60 & 24 & 5 & 10 & 10 & 7,5 & 0 & 2,5 & 0 & 64,75 \\
\hline 3 & 00063 & Person 3 & TK & 80 & 40 & 20 & 60 & 24 & 10 & 10 & 10 & 7,5 & 0 & 2,5 & 0 & 66,00 \\
\hline 4 & 000312 & Person 4 & TK & 80 & 40 & 80 & 30 & 24 & 5 & 7,5 & 5 & 5 & 0 & 2,5 & 0 & 69,75 \\
\hline 5 & 00084 & Person 5 & TK & 80 & 20 & 60 & 30 & 24 & 10 & 10 & 10 & 7,5 & 2,5 & 0 & 2,5 & 64,13 \\
\hline \multirow[t]{2}{*}{6} & 00383 & Person 6 & TK & 80 & 30 & 60 & 30 & 36 & 10 & 10 & 10 & 5 & 0 & 0 & 0 & 67,75 \\
\hline & & Average & & 80 & 35 & 43 & 45 & 24 & 7 & 10 & 9 & 7 & 0 & 2 & 0 & 66 \\
\hline
\end{tabular}

Tabel 3.

Rekap Performance Appraisal tahun 2020

Pencapaian Key Performance Indicator Guru SD

\begin{tabular}{|c|c|c|c|c|c|c|c|c|c|c|c|c|c|c|c|c|c|}
\hline \multirow{5}{*}{ No } & \multirow{5}{*}{ NIK } & \multirow{5}{*}{\multicolumn{3}{|c|}{ Unit Sekolah }} & \multicolumn{13}{|c|}{ Performance Contract (PC) / LB-1 } \\
\hline & & & & & \multirow{3}{*}{ HKE } & \multirow{3}{*}{ PNB } & \multirow{3}{*}{$\mathrm{MPb}$} & \multirow{2}{*}{\multicolumn{6}{|c|}{\begin{tabular}{c|c} 
& Key Performance Indicator \\
& Adm Pembelanjaran
\end{tabular}}} & \multirow{2}{*}{\multicolumn{2}{|c|}{7}} & \multirow{3}{*}{\begin{tabular}{|l}
$\begin{array}{c}\text { Improov } \\
\text { ement } \\
\text { Pemb. }\end{array}$ \\
\end{tabular}} & \multirow{4}{*}{$\begin{array}{l}\text { NIlai } \\
\text { LB-1 } \\
\\
\text { Total } \\
\text { Score }\end{array}$} \\
\hline & & & & & & & & & & & & & & & & & \\
\hline & & & & & & & & $\begin{array}{r}\text { Ev. } \\
\text { KBM } \\
\end{array}$ & BK & Tatib & Presensi & Jad-Pel & Jad-Pik & \multicolumn{2}{|c|}{\begin{tabular}{l|l}
\multicolumn{2}{c}{7} \\
Prest. & Prest.
\end{tabular}} & & \\
\hline & & & & & $15 \%$ & $10 \%$ & $20 \%$ & $15 \%$ & $10 \%$ & $2,5 \%$ & $2,5 \%$ & $2,5 \%$ & $2,5 \%$ & $5 \%$ & $5 \%$ & $10 \%$ & \\
\hline$\nabla$ & 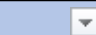 & 2 & 7 & 37 & $4-$ & 5. & 67 & $7 \mathrm{~V}$ & $8 \nabla$ & $9-$ & $10 \nabla$ & $11 \mathrm{~V}$ & $12=$ & $13 \mathrm{~V}$ & $14 \mathrm{~V}$ & $15 \mathrm{~V}$ & $16 \checkmark$ \\
\hline 1 & 00075 & Person 1 & & SD & 80 & 30 & 20 & 60 & 48 & 2,5 & 10 & 10 & 10 & 0 & 2,5 & 0 & 68,25 \\
\hline 2 & 00007 & Person 2 & & SD & 80 & 30 & 20 & 60 & 48 & 2,5 & 10 & 10 & 10 & 0 & 0 & 0 & 67,63 \\
\hline 3 & 00139 & Person 3 & & SD & 80 & 30 & 20 & 60 & 48 & 2,5 & 10 & 10 & 10 & 0 & 0 & 0 & 67,63 \\
\hline 4 & 00140 & Person 4 & & SD & 80 & 10 & 80 & 60 & 12 & 2,5 & 10 & 10 & 10 & 0 & 0 & 0 & 68,63 \\
\hline 5 & 00049 & Person 5 & & SD & 80 & 20 & 20 & 60 & 48 & 10 & 10 & 10 & 10 & 0 & 2,5 & 2,5 & 68,25 \\
\hline 6 & 00005 & Person 6 & & SD & 80 & 40 & 20 & 45 & 36 & 2,5 & 10 & 10 & 10 & 0 & 2,5 & 0 & 64,00 \\
\hline 7 & 00270 & Person 7 & & SD & 80 & 20 & 20 & 45 & 36 & 2,5 & 10 & 10 & 7,5 & 0 & 2,5 & 0 & 58,38 \\
\hline 8 & 00175 & Person 8 & & SD & 80 & 40 & 20 & 45 & 36 & 2,5 & 10 & 10 & 10 & 0 & 0 & 0 & 63,38 \\
\hline 9 & 00176 & Person 9 & & SD & 60 & 30 & 20 & 45 & 48 & 2,5 & 10 & 10 & 10 & 0 & 2,5 & 0 & 59,50 \\
\hline 10 & 00217 & Person 10 & & SD & 60 & 10 & 80 & 45 & 36 & 2,5 & 10 & 10 & 10 & 2,5 & 2,5 & 5 & 68,38 \\
\hline 11 & 00127 & Person 11 & & SD & 80 & 40 & 0 & 45 & 36 & 2,5 & 10 & 10 & 10 & 0 & 2,5 & 2,5 & 59,63 \\
\hline 12 & 00269 & Person 12 & & SD & 60 & 10 & 80 & 45 & 36 & 2,5 & 10 & 10 & 10 & 2,5 & 2,5 & 5 & 68,38 \\
\hline 13 & 00121 & Person 13 & & SD & 80 & 40 & 20 & 45 & 48 & 2,5 & 10 & 10 & 10 & 2.5 & 2,5 & 2,5 & 67,63 \\
\hline 14 & 00006 & Person 14 & & SD & 80 & 20 & 20 & 45 & 36 & 2,5 & 10 & 10 & 10 & 0 & 2,5 & 0 & 59,00 \\
\hline 15 & 00048 & Person 15 & & SD & 80 & 20 & 20 & 60 & 36 & 2,5 & 10 & 10 & 10 & 0 & 0 & 0 & 62,13 \\
\hline 16 & 00452 & Person 16 & & SD & 80 & 20 & 60 & 30 & 48 & 10 & 10 & 10 & 7,5 & 2,5 & 2,5 & 2,5 & 70,75 \\
\hline 17 & 00344 & Person 17 & & SD & 80 & 30 & 80 & 30 & 36 & 10 & 10 & 10 & 7,5 & 0 & 2,5 & 2,5 & 74,63 \\
\hline 18 & 00357 & Person 18 & & SD & 80 & 20 & 60 & 15 & 48 & 10 & 10 & 10 & 7,5 & 0 & 2,5 & 2,5 & 66,38 \\
\hline 19 & 00199 & Person 19 & & SD & 60 & 30 & 60 & 60 & 36 & 10 & 10 & 10 & 7,5 & 2,5 & 2,5 & 2,5 & 72,75 \\
\hline 20 & 00431 & Person 20 & & SD & 60 & 30 & 40 & 45 & 36 & 10 & 10 & 10 & 7,5 & 0 & 2,5 & 2,5 & 63,38 \\
\hline 21 & 00388 & Person 21 & & SD & 60 & 20 & 40 & 45 & 48 & 10 & 10 & 10 & 7,5 & 0 & 2,5 & 2,5 & 63,88 \\
\hline 22 & 00274 & Person 22 & & SD & 60 & 20 & 60 & 15 & 36 & 10 & 10 & 10 & 7,5 & 0 & 0 & 0 & 57,13 \\
\hline 23 & 00293 & Person 23 & & SD & 60 & 20 & 60 & 15 & 48 & 10 & 10 & 10 & 10 & 0 & 0 & 0 & 60,75 \\
\hline 24 & 00385 & Person 24 & & SD & 60 & 40 & 80 & 30 & 0 & 10 & 10 & 10 & 10 & 2,5 & 2,5 & 2,5 & 64,38 \\
\hline 25 & 00273 & Person 25 & & SD & 80 & 30 & 40 & 30 & 12 & 10 & 10 & 10 & 5 & 0 & 0 & 5 & 58,00 \\
\hline & & Average & & & 72,8 & 26 & 41,6 & 43,2 & 37,44 & 5,8 & 10 & 10 & 9 & 0,521 & 1,7 & 1,6 & 64,91 \\
\hline
\end{tabular}


Sri Wahyuni Nur Hidayah, Dian Hidayati, Herlin, Krisna Erwintha Putra

Tabel 4.

Rekap Performance Appraisal tahun 2020

Pencapaian Key Performance Indicator Guru SMP

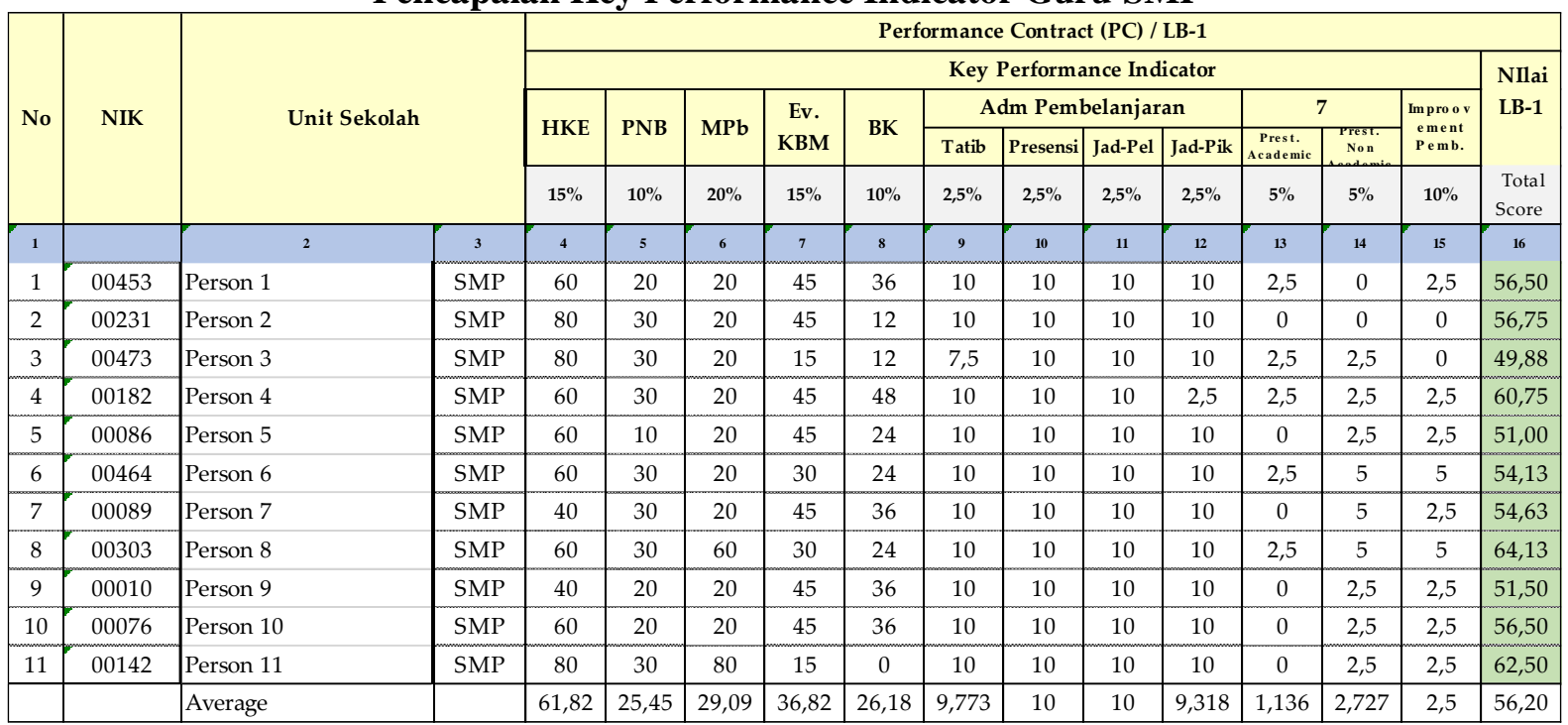

Tabel 5.

Rekap Performance Appraisal tahun 2020

Pencapaian Key Performance Indicator Guru SMK

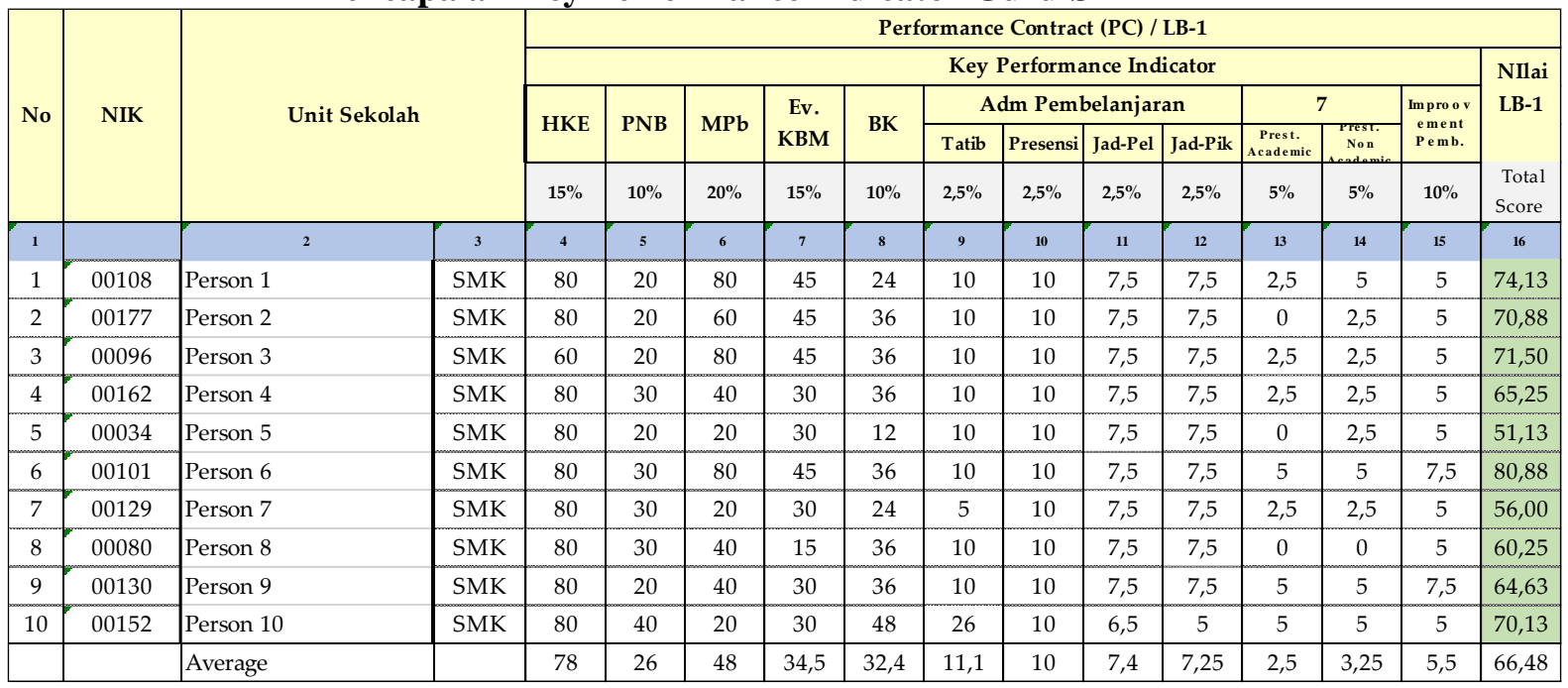


Evaluasi Pencapaian Key Performance Indicator (KPI) untuk Merancang Training Need Analysis (TNA) Kompetensi Guru

Tabel 6.

Rekap Performance Appraisal tahun 2020

Pencapaian Key Performance Indicator Guru per unit Sekolah

\begin{tabular}{|c|c|c|c|c|c|c|c|c|c|c|c|c|c|c|c|}
\hline \multirow{5}{*}{ No } & \multirow{5}{*}{ NIK } & \multirow{5}{*}{ Unit Sekolah } & \multicolumn{13}{|c|}{ Performance Contract (PC) / LB-1 } \\
\hline & & & \multicolumn{12}{|c|}{ Key Performance Indicator } & \multirow{3}{*}{\begin{tabular}{|l} 
NIlai \\
LB-1
\end{tabular}} \\
\hline & & & \multirow[b]{2}{*}{ HKE } & \multirow[b]{2}{*}{ PNB } & \multirow[b]{2}{*}{$\mathrm{MPb}$} & \multirow{2}{*}{$\begin{array}{c}\text { Ev. } \\
\text { KBM }\end{array}$} & \multirow[b]{2}{*}{ BK } & \multicolumn{4}{|c|}{ Adm Pembelanjaran } & \multicolumn{2}{|c|}{7} & \multirow{2}{*}{\begin{tabular}{|c} 
Improov \\
ement \\
Pemb.
\end{tabular}} & \\
\hline & & & & & & & & Tatib & Presensi & Jad-Pel & Jad-Pik & $\begin{array}{c}\text { Prest. } \\
\text { Academic }\end{array}$ & $\begin{array}{c}\text { Prest. } \\
\text { Non } \\
\text { Academic }\end{array}$ & & \\
\hline & & & $15 \%$ & $10 \%$ & $20 \%$ & $15 \%$ & $10 \%$ & $2,5 \%$ & $2,5 \%$ & $2,5 \%$ & $2,5 \%$ & $5 \%$ & $5 \%$ & $10 \%$ & $\begin{array}{r}\text { Total } \\
\text { Score }\end{array}$ \\
\hline 1 & & 2 & 3 & 4 & 5 & 6 & 7 & 8 & 9 & 10 & 11 & 12 & 13 & 14 & 15 \\
\hline 1 & & TK & 80,00 & 35,00 & 43,33 & 45,00 & 24,00 & 7,08 & 9,58 & 9,17 & 6,67 & 0,42 & 1,67 & 0,42 & 65,58 \\
\hline 2 & & SD & 72,80 & 26,00 & 41,60 & 43,20 & 37,44 & 5,80 & 10,00 & 10,00 & 9,00 & 0,52 & 1,70 & 1,60 & 64,91 \\
\hline 3 & & SMP & 61,82 & 25,45 & 29,09 & 36,82 & 26,18 & 9,77 & 10,00 & 10,00 & 9,32 & 1,14 & 2,73 & 2,50 & 56,20 \\
\hline \multirow[t]{2}{*}{4} & & SMK & 78,00 & 26,00 & 48,00 & 34,50 & 32,40 & 11,10 & 10,00 & 7,40 & 7,25 & 2,50 & 3,25 & 5,50 & 66,48 \\
\hline & \multicolumn{2}{|c|}{ Rerata pencapaian tingkat Regional } & 73,15 & 28,11 & 40,51 & 39,88 & 30,01 & 8,44 & 9,90 & 9,14 & 8,06 & 1,14 & 2,34 & 2,50 & 63,29 \\
\hline
\end{tabular}

Dari tabel 6 tersebut di atas, dapat ditampilkan dalam bentuk grafik hasil per indikator dari 4 (empat) unit sekolah sebagai dasar penyusunan Training Need Analysis.

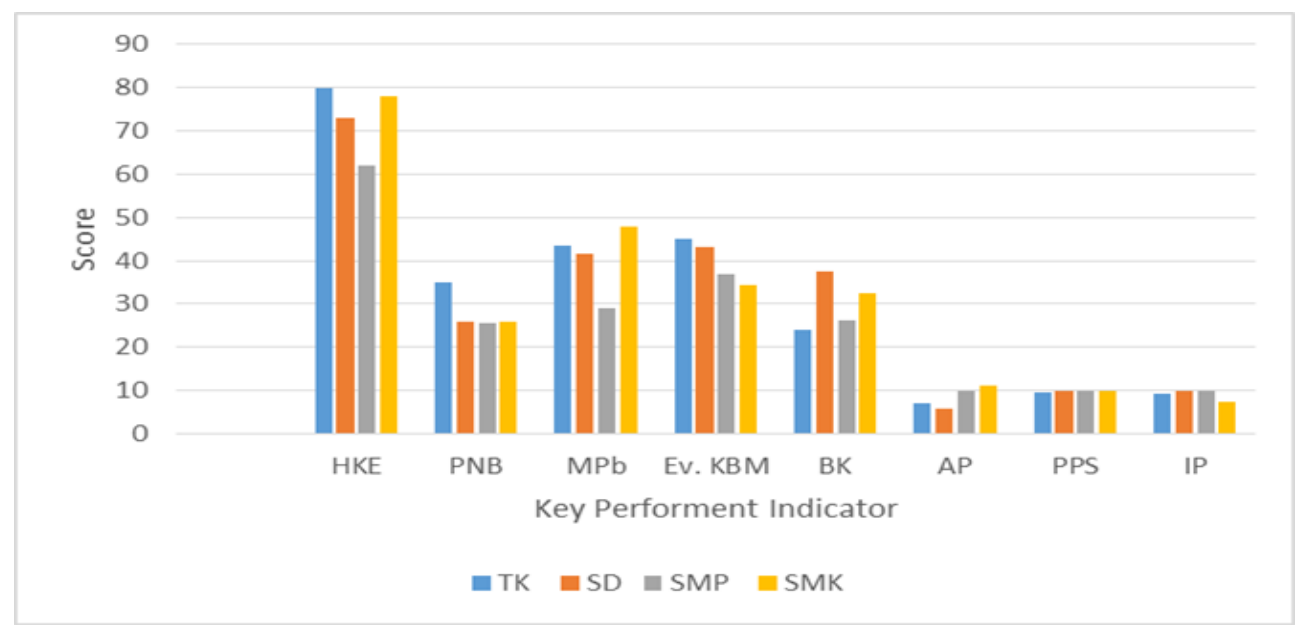

Gambar 2.

Grafik Pencapaian KPI Guru di Sekolah Yayasan

Keterangan gambar:

$\begin{array}{ll}\text { HKE } & \text { : Hari Kerja Efektif } \\ \text { PNB } & \text { : Peningkatan Nilai Pembelajaran } \\ \text { MPB } & \text { : Media Pembelajaran } \\ \text { Ev. KBM } & : \text { Evaluasi Kegiatan Belajar Mengajar } \\ \text { BK } & : \text { Bimbingan Konseling } \\ \text { AP } & : \text { Administrasi Pembelajaran } \\ \text { PPS } & : \text { Peningkatan Prestasi Siswa } \\ \text { IP } & : \text { Improovement Pembelajaran }\end{array}$

Gambar 2 di atas memberikan informasi pencapaian 8 (delapan) Key Performance Indicator Guru dalam performance appraisal Sekolah Yayasan tahun 2020, mulai dari dari jenjang pendidikan TK/PAUD, SD, SMP dan SMK yang berlokasi di Regional Kotawaringin Timur. Dari 8 (delapan) indikator tersebut, 
pencapaian Key performance Indikator dapat di peroleh hasil evaluasi sebagai berikut :

1. Hari Kerja efektif yang diambil dari input kehadiran guru menunjukkan bahwa secara umum baik guru TK, SD, SMP Maupun SMK cukup memiliki kedisplinan tetapi untuk SMP masih memerlukan pembinaan.

2. Peningkatan Nilai Pembelajaran justru didominasi oleh guru TK, kreatifitas guru sangat diperlukan dalam meningkatkan perolehan nilai siswa baik sebagai guru kelas untuk jenjang SD maupun guru mapel untuk tingkat SMP dan SMK.

3. Indikator Media pembelajaran lebih di perhatikan oleh guru-guru SMK dan diikuti oleh guru TK dan guru SD, sedangkan guru SMP masih kurang memperhatikan dalam menyusun media pembelajaran.

4. Evaluasi Pembelajaran belum memberikan data pendukung yang kuat oleh guru guru SD, SMP dan SMK.

5. Bimbingan dan konseling yang seharusnya lebih diutamakan di jenjang sekolah SMP justru kurang tertangani, sedangkan posisi guru BK tersedia untuk SMP.

6. Administrasi pembelajaran terlihat kurang tertib di sekolah TK san SD

7. Peningkatan prestasi siswa, baik akademis maupun non akademis dengan target perolehan kejuaraan olimpiade ditahun 2020 kurang tercapai di semua jenjang pendidikan karena kondisi pandemic.

8. Improovement pembelajaran masih kurang dikembangkan, sedangkan dilain pihak kondisi pandemic di tahun 2020 seharusnya lebih diberikan peran ekstra untuk para guru dalam mengembangkan model pembelajaran baik daring maupun luring.

Dari Evaluasi Pencapaian Key Performance Indicator Guru Yayasan dengan jenjang pendidikan TK, SD, SMP dan SMK maka dapat disusun Training Need Analysis yang sebaiknya dilaksanakan oleh Yayasan untuk memberikan feedback dan follow up dari hasil Performance Apprisal Sekolah Yayasan, ditampilkan di tabel 7.

Tabel 7.

Training Need Analysis Sekolah

\begin{tabular}{|c|c|c|c|c|c|c|}
\hline No & Training & Objective & TK & SD & SMP & SMIK \\
\hline 1 & Disiplin kinerja Guru & $\begin{array}{l}\text { Meningkatkan kedisiplinan guru dalam } \\
\text { perannya sebagai sosok yang diteladani }\end{array}$ & & & $\sqrt{ }$ & \\
\hline 2 & $\begin{array}{l}\text { Improvement } \\
\text { Pembelajaran kreatif dan } \\
\text { menyenangkan }\end{array}$ & $\begin{array}{l}\text { Meningkatkan kreatifitas guru dalam } \\
\text { melaksanakan pembelajaran sehingga } \\
\text { peserta didik menyenangi pelajaran yang } \\
\text { diberikan, daya serap siswa meningkat } \\
\text { dan prestasi menanjak }\end{array}$ & & & $\sqrt{ }$ & $\sqrt{ }$ \\
\hline 3 & $\begin{array}{l}\text { Pengelolaan Administrasi } \\
\text { guru dan Pengembangan } \\
\text { Media Pembelajaran yang } \\
\text { efektif dan informatif }\end{array}$ & $\begin{array}{l}\text { Meningkatkan ketertiban guru dalam } \\
\text { menyajikan media pembelajaran sehingga } \\
\text { pengelolan standar isi dan standar proses } \\
\text { dapat terpenuhi }\end{array}$ & $\sqrt{ }$ & $\sqrt{ }$ & $\sqrt{ }$ & \\
\hline
\end{tabular}




\begin{tabular}{|c|c|c|c|c|c|c|}
\hline 4 & $\begin{array}{l}\text { Administrasi dan evaluasi } \\
\text { penilaian pembelajaran }\end{array}$ & $\begin{array}{l}\text { Meningkatkan sikap evaluative dan } \\
\text { akuntable guru dalam memberikan materi } \\
\text { dihubungkan dengan pencapaian nilai } \\
\text { yang sajikan dalam laporan hasil penilaian } \\
\text { yang informatif. }\end{array}$ & & $\sqrt{ }$ & $\sqrt{ }$ & $\sqrt{ }$ \\
\hline 5 & $\begin{array}{l}\text { Peningkatan Pelayanan } \\
\text { Konseling siswa }\end{array}$ & $\begin{array}{l}\text { Peningkatan layanan khusus } \begin{array}{l}\text { Sekolah } \\
\text { dibidang }\end{array} \text { konseling } \\
\text { permasalahan siswa dan teratasi lebih } \\
\text { awal dan monitoring karakter terlaksana }\end{array}$ & & & $\sqrt{ }$ & \\
\hline 6 & 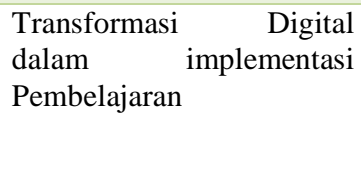 & $\begin{array}{l}\text { Untuk memfasilitasi peningkatan } \\
\text { kompetensi guru dibidang } \text { ITC untuk } \\
\text { menyongsong Education } 4.0 \text { dan } \\
\text { menyetarakan dengan Revolusi Industri } \\
4.0\end{array}$ & $\sqrt{ }$ & $\sqrt{ }$ & $\sqrt{ }$ & $\sqrt{ }$ \\
\hline
\end{tabular}

\section{Kesimpulan}

Dari hasil penelitian yang telah dilakukan dapat disimpulkan bahwa untuk meningkatkan kompetensi guru diperlukan pelatihan-pelatihan baik secara online maupun offline yang memberikan fasilitas upskill bagi para guru di sekolah Yayasan terutama dalam menghadapi perubahan kebijakan pendidikan di era New Normal. Dari hasil penelitian diketahui bahwa hasil pencapaian KPI Guru dalam Performance Apraisal tahun 2020 belum mendapatkan apreasiasi bagi pencapai tertinggi dan belum ada maping kebutuhan pelatihan untuk upskill tenaga pendidik di Yayasan tersebut, Oleh karenanya perlu disusun Training Need Analysis yang mengacu pada pencapaian Key performance Indicator. Atas dasar hasil pencapaian KPI guru Sekolah Yayasan di Kalimantan Tengah, dapat dijadikan parameter tentang keperluan pelatihan guru dengan data pendukung yang obyektif sehingga pelatihan yang diusulkan benar - benar sesuai dengan kebutuhan guru dalam meningkatkan kompetensi diri dan kompetensi dalam mengimplementasikan keilmuannya secara professional.

Dengan analisa tersebut diatas diharapkan dapat meningkatkan pencapaian Key Performance Indicator guru Yayasan dalam Performance Appraisal tahun berikutnya. 
Sri Wahyuni Nur Hidayah, Dian Hidayati, Herlin, Krisna Erwintha Putra

\section{BIBLIOGRAFI}

Amin, Syaihol, \& Nurhadi, Ali. (2020). Urgensi Analisis Kebutuhan Diklat Dalam Meningkatkan Kompetensi Guru Pai Dan Budi Pekerti. Islamic Management: Jurnal Manajemen Pendidikan Islam, 3(02), 83-100. Google Scholar

Arifandi, Ahmad Shidqi Dian. (2020). Evaluasi Kinerja Guru. Edukais: Jurnal Pemikiran Keislaman, 4(2), 106-119. Google Scholar

Fatimaningrum, Arumi Safitri. (2011). Karakteristik Guru Dan Sekolah Yang Efektif Dalam Pembelajaran. Majalah Ilmiah Pembelajaran, 7(2). Google Scholar

Flipse, Steven. (2019). Best practice IV PRISMA KPI analysis tool. Assessment of Responsible Innovation, 272. Google Scholar

Gabcanova, Iveta. (2012). Human Resources Key Performance Indicators. Journal of Competitiveness, 4(1), 117-128. https://doi.org/10.7441/joc.2012.01.09. Google Scholar

Ningtyas, Septiana Ika, \& Sutrisno, Wiriadi. (2020). Analysis Training Needs Assesment dalam Meningkatkan Keprofesian Guru (Studi Kasus di SMK PGRI 28 Jakarta). Research and Development Journal of Education, 6(2), 49. https://doi.org/10.30998/rdje.v6i2.6155. Google Scholar

Nurwahidah, Andi, Sawal, Ahmad, Mulyadi, Mulyadi, Afifudin, Mohammad Thezar, \& Sari, Hasmita. (2021). Perancangan Key Performance Indicator (Kpi) Sebagai Dasar Pengukuran Kinerja Karyawan Di Gudang Sparepart Pada Pt Xyz. Arika, 15(2), 88-93. Google Scholar

Parmenter, David. (2015). Key performance indicators: developing, implementing, and using winning KPIs. John Wiley \& Sons. Google Scholar

Pebrianto, Tinton Tri, \& Noor, M. Tauchid. (2015). Pengaruh Kreativitas Guru Mengajar Dan Minat belajar siswa terhadap hasil prestasi siswa kelas XI jurusan IPS di SMAN Karubaga Kabupaten Tolikara. Jurnal Penelitian Dan Pendidikan IPS, 9(2), 1170-1180. Google Scholar

Qurbani, Derita. (2017). Peningkatan Kompetensi Dosen Dalam Cara Mengajar Melalui Pengembangan Training Need Analysis (Studi Kasus Di Prodi Manajemen Fakultas Ekonomi Universitas Pamulang). JIMF (Jurnal Ilmiah Manajemen Forkamma), 1(1). Google Scholar

Rahman, Rahman, Sakti, Asri Wibawa, Widya, Rani Nurcita, \& Yugafiati, Rasi. (2019). Elementary Education Literacy in the Era of Industrial Revolution 4.0. Advances in Social Science, Education and Humanities Research, 257, 190-193. Google Scholar

Siregar, Pariang Sonang, Wardani, Lia, \& Hatika, Rindi Genesa. (2017). Penerapan Pendekatan Pembelajaran Aktif Inovatif Kreatif Efektif Dan Menyenangkan (Paikem) Pada Pembelajaran Matematika Kelas Iv Sd Negeri 010 Rambah. Jurnal Pemikiran Dan Pengembangan Sekolah Dasar (JP2SD), 5(2), 743. 
Evaluasi Pencapaian Key Performance Indicator (KPI) untuk Merancang Training Need Analysis (TNA) Kompetensi Guru

https://doi.org/10.22219/jp2sd.vol5.no2.743-749 Google Scholar

Warren, Jacques. (2011). Key Performance Indicators (KPI)-Definition and action. London: ATI. Google Scholar

Zubaidi, Ahmad. (2020). Supervisi, Monitoring, dan Evaluasi Pendidikan dalam Peningkatan Mutu Lembaga Formal dan Non-Formal di Pondok Pesantren Nurul Jadid Paiton Probolinggo. GUYUB: Journal of Community Engagement, 1(2), 143-156. Google Scholar

\section{Copyright holder:}

Sri Wahyuni Nur Hidayah, Dian Hidayati, Herlin, Krisna Erwintha Putra (2022)

First publication right:

Syntax Literate: Jurnal Ilmiah Indonesia

This article is licensed under:

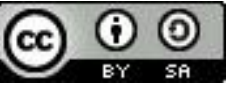

